\title{
Factors Affecting Successful Implementation of Responsible Management Education in Ghanaian Business Schools
}

\author{
Alfred Atakoa ${ }^{1}$ \\ ${ }^{1}$ Kumasi Polytechnic, P. O Box 854 Kumasi, Ghana \\ Correspondence: Alfred Atakoa, Kumasi Polytechnic, P. O Box 854 Kumasi, Ghana. E-mail: \\ aa2464@live.mdx.ac.uk
}

Received: June 5, 2013

Accepted: July 9, $2013 \quad$ Online Published: September 18, 2013

doi:10.5539/ijbm.v8n19p63

URL: http://dx.doi.org/10.5539/ijbm.v8n19p63

\begin{abstract}
Business schools have been criticized failing to acknowledge their role in educating responsible managers that could have helped in solving the recent financial crisis that affected corporate institutions. This has resulted in a number of measures by most business schools in the areas of introduction of responsible management education courses. Nevertheless, the general view prevails that business schools as a whole are making only very little progress in addressing these critical issues on institutional level. The study therefore examines the key factors affecting the implementation of responsible management education in Ghanaian Business Schools.

The study revealed that the most important factors affecting business schools authorities' decisions in the implementation of the concept of responsible management education were; financial constraints, tensions between the university, business schools and national Accreditation Board (NAB). That is not all, but most respondents placed much emphasis on lack of learning environments to promote knowledge, skills and attitudes of students to become responsible business leaders as among the most critical factor affecting the implementation of responsible management education.

Past experience with a CSR agenda and size of the business school were recorded as the least critical factors identified as affecting successful implementation of responsible management education.
\end{abstract}

Keywords: responsible management education, business schools, critical factors, Ghana

\section{Introduction}

This paper presents an empirical analysis of the factors affecting the implementation of Responsible Management Education

Questionnaires and interviews were employed to address the questions of the structural barriers affecting successful implementation of responsible management education by business schools in Ghana; how Business Schools in Ghana implement responsible management education into their curriculum; the nature of the learning environments or scenarios at the business schools in Ghana; how such learning environments or scenarios allow students to construct the relevant skills, attitudes and knowledge to realize sustainable corporate responsibility as future business leaders and finally how business schools foster student learning in order to become responsible business leaders who create sustainable social, environmental and economic value.

The results of the analysis point to two major phenomena. First, that learning environments or scenarios does not allow business schools to construct the relevant skills, attitudes and knowledge to realize sustainable corporate responsibility for its students as future business leaders.

\subsection{Problem Statement}

The changing nature of competition amongst Universities is pushing educational managers to focus on introduction of more degree program and meeting local and international accreditation standards. Most of these universities business schools in Ghana have an obsession with moral character of their students. To most of the business schools, the concept of RME is not seen as another management fad with negligible relevance for practicing manager, but they are affected by a number of factors to its implementations.

\subsection{Objectives of the Study}

Based on the above problem, the general objective of this research is to determine the factors affecting 
successful implementation of responsible management education in Ghanaian business schools. It seeks to investigate why responsible management education still remains an unfulfilled promise by business schools in Ghana despite its importance in the socio-economic development of any given country. Specifically, the study seeks to investigate the following:

The structural barriers affecting successful implementation of responsible management education

The nature of the learning environments or scenarios at the business schools in Ghana in support of responsible management education

How learning environments or scenarios allow business schools to construct the relevant skills, attitudes and knowledge to realize sustainable corporate responsibility for its students as future business leaders

How business schools foster student learning in order to become responsible business leaders who create sustainable social, environmental and economic value

\subsection{Research Questions}

The following research questions will guide the study:

What are the structural barriers affecting successful implementation of responsible management education by business schools in Ghana?

What is the nature of the learning environments or scenarios at the business schools in Ghana?

How do such learning environments or scenarios allow business school to construct the relevant skills, attitudes and knowledge to realize sustainable corporate responsibility for its students as future business leaders?

How can business schools foster student learning in order to become responsible business leaders who create sustainable social, environmental and economic value?

\subsection{Significance of the Study}

The study is to help business schools in Ghana know and appreciate the most critical factors affecting the implementation of RME in order to produce business leaders which live and practice responsible leadership to create sustainable environmental, economic and social value.

\section{Literature Review}

The concept of responsible management education has already become a key issue for many academic institutions (Escudero, 2011). However, it has been said that business schools are increasingly doing more harm than good (Goshal, 2005) based on the fact that most of them tends to ignore the human dimension of businesses and their responsibility towards the social and ecological environment (Navarro, 2008). Graduates from most business schools are being tagged as cold-blooded technocrats due to lack of ecological intelligence, intercultural abilities, interpersonal skills, emotional and, trustworthiness (Mintzberg, 2004). Business schools should be at the fore front of initiating a transformation from career training centers towards enablers of corporate responsibility (Bieger, 2011).

\subsection{Responsible Management Education in Practice}

Responsible Management Education has already become a key issue for many academic institutions (Escudero, 2011).

It is evident that the principles for responsible management education can only be justified if they trickle down to the institutional and educational level of academic organizations (for many practical examples see Escudero, Albareda, Alcaraz, Weybrecht \& Csuri, 2012).

Professors and lecturers at these business schools do not act in the best interests of the students and socio-economic development of the country they are representing but rather on their own self-interest (Khurana and Penrice, 2011). It is evident that the principles for responsible management education can only be justified if they trickle down to the institutional and educational level of academic organizations (Escudero, et al, 2012).

Shareholder value paradigm and profit maximization has recently dominated management education in Ghana. Thus, the aim of educating future business leaders acting beyond pure self-interest has taken a back seat within most universities business schools' curriculum (Losada, Martell \& Lozano, 2011).

Academic institutions are being called upon to acknowledge their responsibility towards sustainable ethical education of their students (Morsing \& Rovira, 2011; Vervoort Isler \& Teta, 2012b). To acknowledge such responsibilities, Nicholson \& DeMoss (2009) posits that business schools should alter their curricula to reflect more on socially responsible and market-driven programs. This is particularly important as it has been revealed 
that US based high ranking business schools have not only fails to improve the moral character of students, but have also weakens it (Segon \& Booth, 2009).

\subsection{Responsible Management Education Model}

Business schools are therefore supposed to emphasize the integration of a normative and strategic perspective to achieve a holistic understanding of management.

Schüz, (2012) posits that responsible management education at business schools should be focused on the goal of Sustainable Corporate Responsibility. This is includes creation of sustainable environmental, social and economic.

The content of responsible management education consists of the role, dynamics, and impact of corporations in creating social, environmental and economic value in interactions with their stakeholders.

The outcome of responsible management education is business leaders which live and practice responsible leadership to create sustainable social, environmental and economic value.

The learning processes to achieve the above outcome take place within learning environments or learning scenarios which allow students to construct the relevant knowledge, skills and attitudes to realize sustainable corporate responsibility as future business leaders.

Furthermore, learning does include a meta-cognitive process enabling students to question, explore and make meaning of the values and assumptions that guide their business decision-making process.

The normative basis of responsible management education consists of shared values and a constant meta-cognitive reflection of the specific context.

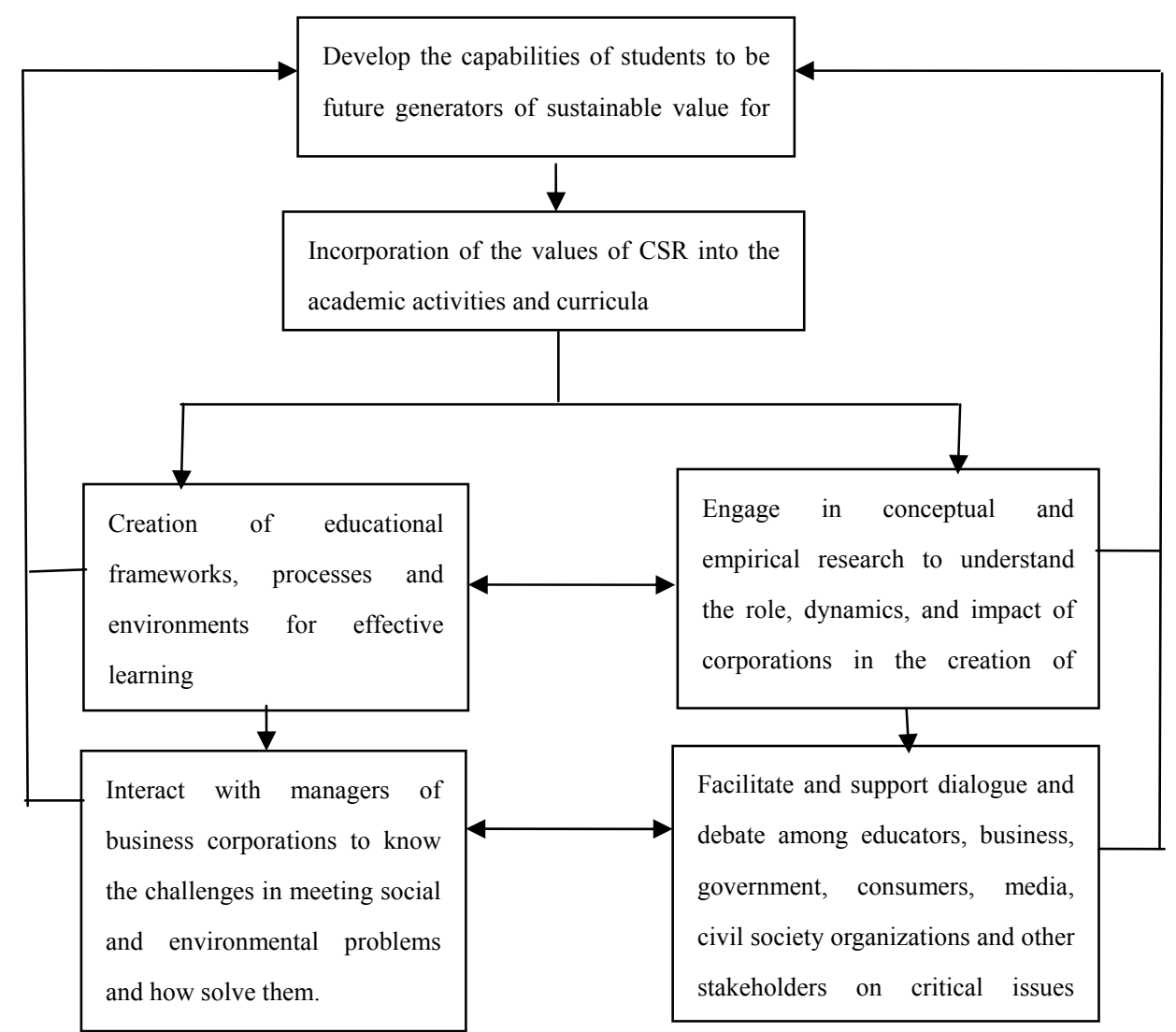

Figure 1. Constructivist learning environments for responsible management education

Source: author's own construct (2013).

The above figure includes specific assumptions about effective learning for responsible leadership. If students are to be seen as future generators of sustainable value for business and society, as indicated in the above figure, 
there is the need for business schools to create enabling learning environments to promote knowledge, skills and attitudes of its students to become responsible business leaders. This require fundamental change from a mere Market-Based Performance Matrices to proactive integration of responsible management education into the school's curricula since according to Matten \& Moon (2004), they can no longer be a brain washing institutions educating their graduates only in relatively narrow shareholder value ideology.

According to Mehran Nejati et al, (2012) business schools should be seen as large corporations by demonstrating responsibility for stakeholders and society as a whole. To be able to undertake such responsibilities, Mehran Nejati et al (2012) proposed seven strands that make up Corporate Social Responsibility for business schools. These include corporate governance, student issues, community involvement and being concern about the environment it operates. These according to the authors help business schools manage potential conflict, create an ongoing stream of satisfied alumni and attract new students.

It is clear from the reviewed literatures that there is limited research work on the factors affecting the implementation of the concept of responsible management amongst Business schools in Ghana.

Study by Maignan \& Ralston (2002) revealed that $53 \%$ of American schools explicitly stated the concept at the schools' websites; only 25\% from Dutch schools and 29\% from French schools. The picture is obscure in developing country like Ghana. While the literatures are rich in suggesting the role of business schools in educating responsible managers, there appears to be no published knowledge on the structural barriers affecting successful implementation of responsible management education by business schools. This issue is worthy of studying.

\section{Methodology}

The research design used was a descriptive design. According to Cooper and Schindler (2003), descriptive studies are concerned with descriptions of phenomenon or characteristics associated with a subject population. The characteristics of groups of numbers of representing information or data are called descriptive statistics (Kay, 1997). These studies are also concerned with discovery of associations sampling different variables. This method allows collection of data from a large number of potential respondents at relatively low costs (Saunders, Lewis \& Thornhill, 2007).

A survey was employed for collection of the primary data. A questionnaire was administered; confidentiality and anonymity of the respondents were assured. This design was effective to describe this study, as its purpose was to investigate factors affecting successful implementation of responsible management education by business schools in Ghana. This ensured an in-depth description of the situation.

\section{Sampling Frame}

A sampling frame is designed as the list of elements from which the sample will be actually drawn. Ideally, it is a complete and correct list of population members only (Cooper \& Schindler, 2001). The sample frame was developed from a list of employees from business schools in Ghana. Public and private universities, with more than 30 employees within their business schools were extracted.

\subsection{Sampling Technique}

Stratified random sampling technique was used. As pointed out by deVaus (2002), the sample frame in some cases is already divided into strata (Easterby-Smith et al, 2002).

The sampling frame was drawn from each stratum based on the stratum's share of the total population. This approach was chosen since it had a higher statistical efficiency than simple random sampling and it provides adequate data for analyzing the various subpopulations and finally it enables different research methods and procedures to be used in different strata (Patton, 2002; Cooper and Schindler, 2003). The strata were divided into the type of university (public and private) and role at the business school (Deans, Heads of department).

\subsection{Sample Size}

The sample size for this study was selected based on the size used in similar research while taking into account the time and resource limitations of the current study. According to Saunders et al, (2007), the larger your sample size, the lower the likely error in generalizing to the population. This study used a sample size of 19 respondents.

The questionnaires were delivered; they were collected immediately from certain respondents after they had filled in their answers. However, those respondents who were not able to fill in immediately, one week was reserved to distribute the questionnaires and some were submitted on email and sent to the respondents. Follow ups were then conducted. The questions were designed based on the research questions, the questions were standardized, valid, 
and reliable for obtaining the necessary data required. The importance of correct and timely completion of the questionnaires was highlighted including confidentiality and anonymity. Completion of the questionnaires was carefully checked

\section{Findings}

Table 1. Length of time worked in the organization

\begin{tabular}{lccc}
\hline Length of time & Frequency & Valid Percent \\
\hline 0-4 Years & 2 & 10.5 \\
& 5-9 Years & 6 & 31.5 \\
10-14 Years & 9 & 47.5 \\
Over 20 Years & 2 & 10.5 \\
Total & 19 & 100.0 \\
\hline
\end{tabular}

$10.5 \%$ of the employees had worked for less than 4 years, $31.5 \%$ had worked for a period between $5-9$ years. Those who had worked between $10-14$ years were $47.5 \%$ while $10.5 \%$ had worked for over 20 years.

Table 2. Implementers of RME in business schools

\begin{tabular}{lcc}
\hline \multicolumn{1}{c}{ Level of management } & Frequency & Valid Percent \\
\hline Faculty Deans \& Deputies & 6 & 31.5 \\
Heads of Departments & 9 & 47.4 \\
Curriculum Coordinators & 4 & 21.1 \\
Total & 19 & 100 \\
\hline
\end{tabular}

Among the respondents, $31.1 \%$ were Deans and Deputy Deans of Faculty of Business, $47.4 \%$ occupied positions as heads of departments within the various business schools, $21.1 \%$ were curriculum Coordinators.

Table 3(a). Mean and standard deviation showing factors affecting successful implementation of RME

\begin{tabular}{llcc}
\hline Factors & Mean & Std. Dev & Coef. V \\
\hline Financial constraints & 4.81 & 1.35 & $0.28^{* * *}$ \\
& 4.54 & 1.22 & $0.44^{* * *}$ \\
Tensions between the university, business schools and national Accreditation Board (NAB) & 5.21 & 1.04 & $0.42^{* * *}$ \\
Lack of learning environments to promote knowledge, skills and attitudes of students to & 3.61 & 1.32 & $0.39^{* * *}$ \\
become responsible business leaders & & \\
Personality & 3.52 & 1.62 & $0.34^{* * *}$ \\
More focus on Market-Based Performance Matrices like business school ranking & 2.04 & 1.02 & $0.18^{* *}$ \\
How close the mall is from me can influence my decision to shop there & 2.15 & 1.09 & $0.11^{* *}$ \\
Top management at the university sees RME as another management fad with negligible & 1.91 & 0.97 & $0.31^{* *}$ \\
relevance for practicing managers & & 1.07 & 0.08 \\
Past experience with a CSR agenda & 1.08 & 1.01 & $0.21^{*}$ \\
Size of the business school & & $0.11^{*}$ \\
\hline
\end{tabular}

*** - Most Critical.

** - Critical.

* Least Critical. 
Table 3(b). Visual binning

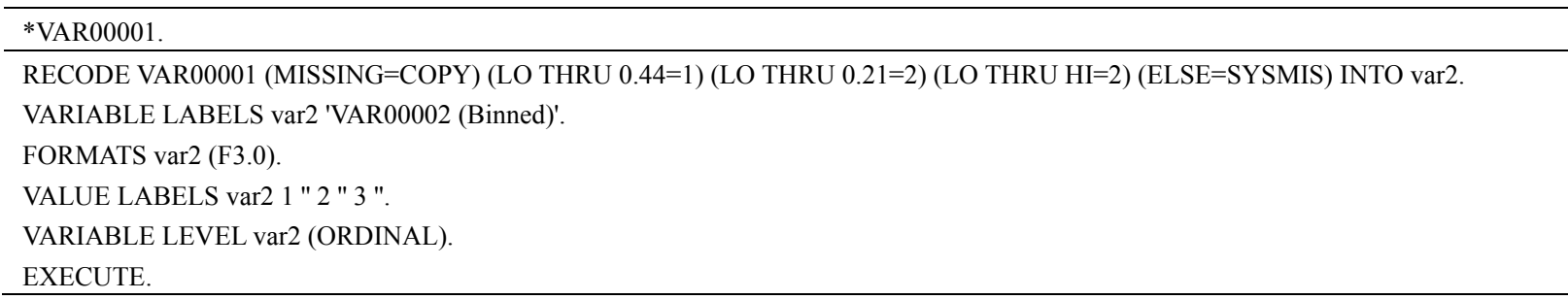

A visual binning on SPSS was run to test the coefficient values in order to rank them as most critical, critical and least critical factors. The most critical factors affecting successful implementation of responsible management education recorded coefficient value of 0.28 to 0.34 . However, the critical factors ranged from 0.18 to 0.31 while the least critical factors ranged from 0.21 to 0.11 coefficient variation.

The most important factors affecting business schools authorities' decisions in the implementation of the concept of responsible management education were; financial constraints, tensions between the university, business schools and national Accreditation Board (NAB). That is not all, but most respondents placed much emphasis on lack of learning environments to promote knowledge, skills and attitudes of students to become responsible business leaders as among the most critical factor affecting the implementation of responsible management education.

Past experience with a CSR agenda and size of the business school were recorded as the least critical factors identified to affect the successful implementation of responsible management education. The study is therefore in support of advice by Nicholson \& DeMoss (2009) who posits that business schools should alter their curricula to reflect more on socially responsible and market-driven programs.

Table 4. The T-test for influencing factors

\begin{tabular}{|c|c|c|c|c|c|c|c|c|c|c|}
\hline \multicolumn{11}{|c|}{ One-Sample Statistics } \\
\hline & \multirow[t]{2}{*}{$\mathrm{N}$} & \multirow[t]{2}{*}{ Mean } & \multirow[t]{2}{*}{$\begin{array}{c}\text { Std. } \\
\text { Deviation }\end{array}$} & \multirow[t]{2}{*}{$\begin{array}{l}\text { Std. } \\
\text { Error } \\
\text { Mean }\end{array}$} & \multirow[t]{2}{*}{$\mathrm{t}$} & \multirow[t]{2}{*}{$\mathrm{df}$} & \multirow[t]{2}{*}{$\begin{array}{c}\text { Sig. } \\
\text { (2-tailed) }\end{array}$} & \multirow[t]{2}{*}{$\begin{array}{c}\text { Mean } \\
\text { Difference }\end{array}$} & \multicolumn{2}{|c|}{$\begin{array}{c}95 \% \text { Confidence } \\
\text { Interval of the } \\
\text { Difference }\end{array}$} \\
\hline & & & & & & & & & Lower & Upper \\
\hline Most_Critical_Factors1 & 19 & 3.6782 & 0.57243 & 0.0563 & 13.866 & 19 & 0 & 0.77928 & 0.6673 & 0.8913 \\
\hline Critical_Factors 1 & 19 & 3.0575 & 0.67384 & 0.08123 & 0.644 & 19 & 0.521 & 0.05878 & -0.1231 & 0.2406 \\
\hline Least_Critical_Factors1 & 19 & 3.0613 & 0.91278 & 0.08722 & 0.551 & 19 & 0.583 & 0.05135 & -0.1344 & 0.2371 \\
\hline
\end{tabular}

Using the test value of 2, the results were neutral for the most critical factors produced a mean of 2.78 which was leaning towards 3 , least critical factors 2.05 and 2.06 was the mean of critical factors.

My school facilitates and support dialogue and debate among educators, businesses, government, consumers, media, civil society organizations and other stakeholders on critical issues related to RME.

Table 5. Relationship between business schools and stakeholders

\begin{tabular}{cccc}
\hline Responses & Frequency & Percentage & Cumulative \% \\
\hline Strongly disagree & 5 & 26.3 & 26.3 \\
Disagree & 6 & 31.6 & 57.9 \\
Neutral & 1 & 5.3 & 63.2 \\
Agree & 4 & 21.1 & 84.3 \\
Strongly agree & 3 & 15.7 & 100 \\
Total & 19 & 100 & \\
\hline
\end{tabular}

Source: Author's Field work, 2013.

With regard to the above statement, it revealed that, a greater proportion of the respondents (6) strongly disagreed with the statement that their school facilitates and support dialogue and debate among educators, 
businesses, government, consumers, media, civil society organizations and other stakeholders on critical issues related to RME. This constituted forty-four percent (31.6\%) of them. Only 15.7\% agreed with the assertion.

It is therefore clear from the above revelation that the heads of the faculty of business schools and departmental heads has a significant role to play in the implementation of the concept of responsible management education. These academic personalities represent the schools at the market place and transmit intelligence within the school about the policies of the university.

While there has traditionally been a call for Business schools to be given greater responsibility and autonomy to implement the concept of responsible management education, the study has revealed that there are tensions between the various things in the university, business schools and national Accreditation Board (NAB) which are affecting the implementation of RME by the heads of Business Schools.

Personality of those in charge of the business school appears to be key factors in the implementation of RME. Previous studies has identified a list of personality attributes which are successful for leaders in business schools environment (Middlehurst, 1993, Ramsden, 1998, Watson, 2002). These are not at odds with general studies of leadership which show charisma (Bass 1985), emotional intelligence (Goleman 2000), and responsiveness to followers (Hersey \& Blanchard 1982) are key dimensions for implementing a policy like RME. This study has shown that business school leadership quest to the implementation of RME is best described in the way Lorange (2002) has done, although his findings are extended to other faculties within a particular university.

A consequence is that other capabilities do not feature as so essential if Deans of business school to implement RME successfully. As indicated by Harman (2002) although a threshold level of academic credentials is necessary for the Deans and heads of departments to implement RME within financial constraints as indicated in table 3, this is less significant than actual or potential managerial experience. In the same way commercial acumen may be helpful but is not a pre requisite to the implementation of RME in a particular business school.

Table 6. Cross tabulation analysis of business school rankings and RME

\begin{tabular}{|c|c|c|c|c|c|c|c|}
\hline & & & \multicolumn{4}{|c|}{ I seldom think about the university's rank when making RME decisions } & \multirow{2}{*}{ Total } \\
\hline & & & Strongly Disagree & Disagree & Neutral & Agree & \\
\hline \multirow{4}{*}{ 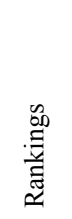 } & \multirow{2}{*}{ Influenced RME } & Count & 3 & 2 & 1 & 4 & 10 \\
\hline & & $\%$ & $30 \%$ & $20 \%$ & $10 \%$ & $40 \%$ & $100 \%$ \\
\hline & \multirow{2}{*}{ Don’t influenced RME } & Count & 6 & 1 & 0 & 2 & 9 \\
\hline & & $\%$ & $66 \%$ & $11 \%$ & $0 \%$ & $23 \%$ & $100 \%$ \\
\hline \multirow{2}{*}{ Total } & & Count & 9 & 3 & 1 & 6 & 19 \\
\hline & & $\%$ & $47.4 \%$ & $15.8 \%$ & $5.3 \%$ & $31.5 \%$ & $100 \%$ \\
\hline
\end{tabular}

Table 6 represents a cross tabulation of the relationship between RME and Market-Based Performance Matrices (rankings). From the findings, 66\% strongly disagreed with the idea that university rankings has an influence on their decision to implement the concept of RME, $11 \%$ disagreed to the idea and $23 \%$ agreed to the idea. This finding is in line with N. C Liu, \& Y Cheng (2009) ideas that since most of the criteria for ranking the universities are based on mere numbers, it does not measure the quality of teaching or the quality of humanities hence it should not distract universities from its core functions.

\section{Conclusions and Recommendations}

The results are analyzed with reference to the literature review and in terms of the research questions. Based on the literature review undertaken by the study, the expectations were that market-based performance matrices such as rankings will be the main factor affecting successful implementation of responsible Management Education in Ghanaian Business Schools. However, majority of the respondents were seen as being influenced by non-market based performance matrices such as financial constraints, tensions between the university, business schools and national Accreditation Board (NAB).

The study of factors influencing successful implementation of RME helps business schools achieve their mandate of developing the capabilities of students to be future generators of sustainable value for businesses.

Implementation of Responsible Management Education by business schools is influenced by a number of factors such financial constraints, lack of top management support. 
Most researchers like Morsing \& Rovira, (2011); Vervoort Isler \& Teta, (2012b); Escudero, et al, (2012) on the field of Responsible management Education are of the view that academic institutions should acknowledge their responsibility towards sustainable ethical education of their students and have a positive impact on organizations by creating social, environmental and economic value in interactions with their stakeholders. Early investigations by academics (Losada, Martell \& Lozano, 2011, Schüz, 2012) have indicated that a variety of characteristics are vital to successful implementation of RME.

The aim of this study was to investigate the factors affecting successful implementation of Responsible Management Education in Ghanaian business schools. As one of the only 7 emerging sub-Saharan economies with a liberalized economy (Appiah-Adu \& Blankson, 2012), Ghana was chosen as the context for this study because of the possible disproportionate academic imbalances that may result from the influx of foreign business schools and courses Besides, Ghanaians came into contact with westerners and their educational practices as a far back as 1940 and it would also be interesting to know how such interaction might have influence their implementation of responsible management education.

The research was guided by the following research questions; first - the structural barriers affecting successful implementation of responsible management education

Secondly, the nature of the learning environments or scenarios at the business schools in Ghana in support of responsible management education

Moreover, it looks into how learning environments or scenarios allow students to construct the relevant skills, attitudes and knowledge to realize sustainable corporate responsibility as future business leaders.

Finally, the study examines how business schools foster student learning in order to become responsible business leaders who create sustainable social, environmental and economic value.

The research methodology used was a descriptive design. A survey was employed for collection of the primary data. The sample frame was developed from a list of business schools in different deferent tertiary institutions in Ghana. This restriction is necessary because of time and resource constraints. A sample size of 25 out of which active response came from 19 respondents. The study engaged the use of structured questionnaires that were pilot tested in order to ensure that the questions asked were relevant, data validity as well as reliability. Data coding was done using Microsoft Excel in combination with SPSS to generate the descriptive statistics for instance the frequencies as well as the percentages. The results were then presented in form of tables, as well as figures.

\section{Recommendations}

The study has clearly indicated that business schools in Ghana acknowledged their role in educating responsible managers. However, a number of factors affect business schools in the successful implementation of the concept.

This has been discussed in the study and therefore recommendations for improvements would include the following:

RME should be part of the accreditation program and ranking systems in Ghana.

The business schools in Ghana should offer CSR scholarships to students.

The business schools in Ghana should offer courses like MBA in Business Ethics, Citizenship and Governance. Rather than embedding them in their existing undergraduate and post graduate programs.

\section{Recommendations for Further Studies}

The primary limitation of the current study is the generalizability of the results. Due to time constraints and restraints on financial resources, the researcher recommends that further studies be carried out in different countries. The study samples were only drawn from public universities in Ghana. Because different conditions for implementing RME decisions might be caused by unbalanced development of economic areas, this research may not apply to other zones of the country or to all the tertiary institutions in Ghana as a whole. However, this limitation also implies future research opportunities.

Another research opportunity would involve studying and comparing factors influencing student's decisions across different countries or regions of the world. For instance, are the factors affecting successful implementation of Responsible Management Education in American or Japanese business schools similar to those in Ghana? 


\section{Acknowledgements}

The author would like to acknowledge the contribution offered by the long discussions with the Dean of Faculty of Business, Christian Service University, Ghana.

I also would like to thank Dr. Jyoti Navare, Dr. Asiama Yeboah and Dr. Alfred Owusu.

I am indebted to one anonymous referee whose comments and suggestions have significantly improved the quality of the paper. Usual disclaimers apply.

The comments and suggestions of participants at the various universities business schools during the interviews are much appreciated.

\section{References}

Armstrong, J. S., \& Tad, S. (1994). Business School Prestige: Research versus Teaching. Energy \& Environment $13-43$. Retrieved from http://marketing.wharton.upenn.edu/documents/research/Business\%20School\%20Prestige.pdf

Barthelmess, P. (2013). Different Shades of Green: Comparative Study on Nature Relatedness and Ecologic Consciousness among Czech, South Korean and Swiss Students.

Bieger, T. (2011). Business Schools - From Career Training Centers Towards Enablers of CSR: A New Vision for Teaching at Business Schools. In Morsing, M., \& Rovira, A. S. (Eds.), Business Schools and their Contribution to Society (pp. 104-113). London: Sage Publications.

Bieger, T. (2011). Business Schools-From Career Training Centers Towards Enablers of CSR: A New Vision for Teaching at Business Schools. In Morsing, M., \& Rovira, A. S. (Eds.), Business Schools and their Contribution to Society (pp. 104-113). London: Sage Publications.

Dubs, R. (2009). Lehrerverhalten. Ein Beitrag zur Interaktion von Lehrenden und Lernenden im Unterricht. Zich: Verlag SKV.

Escudero, M. (2011). PRME and Four Theses on the Future of Management Education. In Morsing, M., \& Rovira, A. S. (Eds.), Business Schools and their Contribution to Society (pp. 201-212). London: Sage Publications.

Escudero, M. (2011). PRME and Four Theses on the Future of Management Education. In Morsing, M., \& Rovira, A. S. (Eds.), Business Schools and their Contribution to Society (pp. 201-212). London: Sage Publications.

Escudero, M., Albareda, L., Alcaraz, J. M., Weybrecht, G., \& Csuri, M. (2012). Inspirational Guide For The Implementation of PRME: Placing sustainability at the heart of management education. Leeds: PRME.

Escudero, M., Albareda, L., Alcaraz, J. M., Weybrecht, G., \& Csuri, M. (2012). Inspirational Guide for the Implementation of PRME: Placing sustainability at the heart of management education. Leeds: PRME.

Ghoshal, S. (2005). Bad management theories are destroying good management practices. Academy of Management Learning and Education, 4(1), 75-91. http://dx.doi.org/10.5465/AMLE.2005.16132558

Khurana, R., \& Penrice, D. (2011). Business Education: the American Trajectory. In Morsing, M., \& Rovira, A. S. (Eds.), Business Schools and their Contribution to Society (pp. 3-15). London: Sage Publications.

Losada, C., Matell, J., \& Losano, J. M. (2011). Responsible Business Education: not a question of curriculum but a raison d'être for business schools. In Morsing, M., \& Rovira, A. S. (Eds.), Business Schools and their Contribution to Society (pp. 163-174). London: Sage Publications.

Mintzberg, H. (2004). Managers Not MBAs: A Hard Look at the Soft Practice of Managing and Management Development. San Francisco: Berrett-Koehler Publishers.

Morsing, M., \& Rovira, A. S. (2011). Business Schools and their Contribution to Society. London: Sage Publications.

Navarro, C. (2008). The MBA core curricula of top-ranked US business schools: a study in failure. Academy of Management Learning and Education, 7(1), 108-123. http://dx.doi.org/10.5465/AMLE.2008.31413868

Starkey, K., \& Tempest, S. (2009). The winter of our discontent: the design challenge for business schools. Academy of Management Learning and Education, 8(4), 576-586. http://dx.doi.org/10.5465/AMLE.2009.47785476

Vervoort Isler, P., \& Teta, A. (2012a). BWL Skills/Key Concepts. 
Vervoort Isler, P., \& Teta, A. (2012b). Die Chefs von morgen: kompetent und kritisch. IO Management, 5, $12-15$.

Wilson, A., Lenssen, G., \& Hind, P. (2006). Leadership Qualities and Management Competencies for Corporate Responsibility. Ashridge and EABIS.

\section{Copyrights}

Copyright for this article is retained by the author(s), with first publication rights granted to the journal.

This is an open-access article distributed under the terms and conditions of the Creative Commons Attribution license (http://creativecommons.org/licenses/by/3.0/). 